\title{
ANALISIS PENGARUH KINERJA KEUANGAN TERHADAP HARGA SAHAM PT. BISI INTERNASIONAL TBK PERIODE 2011-2015
}

\author{
MURSIDIN SABARdan SRI ASTUTY RATNASARI MANGGU
}

Program Studi Akuntansi Fakultas Ekonomi Universitas Sulawesi Barat email: mursidinsbr@gmail.com, sriastutyrm@gmail.com

\begin{abstract}
ABSTRAK
Penelitian ini bertujuan untuk mengetahui bagaimana pengaruh kinerja keuangan terhadap harga saham pada PT. Bisi Internasional Tbk. Pada penelitian ini digunakan analisis rasio keuangan yaitu Return On Asset (ROA), Earning Per Share (EPS), dan Price Earning Ratio (PER). Periode penelitian ini dimulai dari tahun 2011-2015. Hipotesis yang dikemukakan pada penelitian ini adalah terdapat pengaruh kinerja keuangan terhadap harga saham secara parsial dan secara simultan juga terdapat pengaruh kinerja keuangan terhadap harga saham. Metode analisis yang digunakan untuk melihat pengaruh kinerja keuangan terhadap harga saham pada PT. Bisi Internasional Tbk adalah analisis statistik deskriptif.

Pengujian hipotesis dilakukan dengan uji statistik secara parsial (Uji T) dan uji statistik secara simultan (uji F) dengan $\alpha=5 \%$. Penganalisaan data menggunakan software pengolahan data statistik yaitu SPSS 23.00 for windows. Hasil uji secara parsial (uji T) menunjukkan bahwa kinerja keuangan yang diwakili rasio Return On Asset (ROA) dengan signifikansi $0,03<\alpha 0,05$ dan Price Earning Ratio (PER) dengan signifikansi $0,000<\alpha 0,05$ berpengaruh signifikan terhadap harga saham, sedangkanEarning Per Share (EPS) tidak berpengaruh terhadap harga saham dengan signifikansi 0,482 $>\alpha 0,05$. Hasil uji secara simultan (uji F) menunjukkan bahwa semua variabel independen yaitu Return On Asset (ROA), Earning Per Share (EPS), danPrice Earning Ratio (PER) berpengaruh signifikan terhadap harga saham dengan signifikansi $0,001<\alpha 0,05$. Nilai koefisien determinasi sebesar 58,1\% yang berarti hubungan antara variabel bebas Return On Asset, Earning Per Share dan Price Earning Ratio secara bersama-sama terhadap harga saham memiliki hubungan yang erat.
\end{abstract}

Kata Kunci : Rasio Kinerja Keuangan, Harga Saham, Pengaruh Parsial, Pengaruh Simultan, Koefisien Determinasi.

\section{PENDAHULUAN}

\section{A. Latar Belakang}

Suatu perusahaan diharapkan dapat terus berkembang. Sementara pengembangan tersebut membutuhkan modal. Modal itu sendiri menjadi salah satu aspek penting dalam perusahaan baik dalam pembukaan bisnis maupun pengembangannya. Oleh karena itu, perusahaan harus menentukan seberapa banyak modal yang diperlukan untuk membiayai perusahaan. Sumber dana bagi perusahaan dapat diperoleh dari dalam maupun luar perusahaan. Dana dari dalam perusahaan, yaitu melalui laba ditahan dan depresiasi serta dana dari luar perusahaan yaitu dana yang berasal dari para kreditur dan investasi pihak ketiga.Namun dana yang berasal dari pinjaman kreditur, serta investasi asing dirasa masih 
kurang. Oleh sebab itu banyak perusahaan yang memilih pasar modal sebagai sarana penambah modal mereka.

Pasar modal merupakan wadah alternatif selain bank dan lembaga keuangan non bank bagi para investor untuk melakukan penanaman modal (investasi). Menurut Martono dan Agus Harjito, (2005) pasar modal (captal market) adalah suatu pasar di mana dana-dana jangka panjang maupun modal sendiri diperdagangkan. Dana jangka panjang yang diperdagangkan tersebut diwujudkan dalam surat-surat beharga. Jenis surat berharga yang diperjual belikan di pasar modal memiliki jatuh tempo lebih dari satu tahun dan ada yang tidak memiliki jatuh tempo.

Masyarakat yang sudah mengenal pasar modal, banyak yang tertarik untuk memiliki saham dari sebuah perusahaan sebagai bukti kepemilikannya akan perusahaan tersebut. Namun sebelum masyarakat memutuskan akan menginvestasi dananya dipasar modal ada kegiatan yang terpenting untuk dilakukan, yaitu penilaian dengan cermat terhadap emiten suatu perusahaan. Penilaian emiten suatu perusahaan didapat dari informasi yang tersedia di pasar modal sehingga masyarakat dapat dengan mudah memperoleh informasi tentang penilaian emiten suatu perusahaan. Salah satu aspek yang dinilai oleh masyarakat dalam investasi adalah kinerja keuangan perusahaan yang diukur dari laporan keuangan perusahaan. Oleh karena itu perusahaan akan selalu mempublikasikan laporan keuangannya agar para calon investor dapat mengetahui bagaimana kinerja perusahaan, dan prospek perusahaan tersebut kedepan. Dengan kata lain, sebuah laporan keuangan dapat dijadikan bahan pertimbangan bagi para calon investor saat melakukan investasi.

Menurut Martono dan Agus Harjito (2005) menyatakan bahwa rasio keuangan berguna untuk mengetahui informasi posisi keuangan dan kinerja keuangan masa lalu, masa sekarang dan meramalkan posisi dan kinerja keuanga di masa yang akan datang. Dengan rasio keuangan memungkinkan investor menilai kondisi keuangan dan hasil operasi perusahaan saat ini dan di masa lalu serta sebagai pedoman para investor mengenai kinerja masa lalu dan masa mendatang.

Artatik (2007) dalam penelitiannya yang berjudul Pengaruh Earning Per Share (EPS), Price Earning Ratio (PER), Financial Laverage (FL) dan Return On Equity (ROE) Terhadap Harga Saham PerusahaanOtomotif di Bursa Efek Indonesia". Hasil penelitian secara parsial menunjukkan variabel EPSdan PER mempunyai pengaruh signifikan terhadap harga saham sedangkan FL dan ROE tidak berpengaruh signifikan terhadap harga saham. Hasil pengujian secara simultan menunjukkan variabel EPS, PER, FL, dan ROEmempunyai pengaruh signifikan terhadap harga saham. Rendra Yuli Aditya (2014) dalam penelitiannya yang berjudul Pengaruh Kinerja Keuangan Terhadap Harga Saham Pada Perusahaan Rokok di Bursa Efek Indonesia. Hasil pengujian secara parsial variabel return on asset (ROA), earning per share (EPS), dan price earning ratio (PER) berpengaruh terhadap harga saham, hanya variabel retrun on asset yang tidak menunjukkan pengaruh signifikan terhadap harga saham. Hal ini diindikasikan dengan nilai signifikansi yang dihasilkan variabel tersebut di atas 5\%. Sedangkan variabel earning per share (EPS)dan priceearning ratio (PER) masing-masing berpengaruh signifikan terhadap harga saham. Hasil pengujian secara simultan menunjukkan pengaruh 
variabel return on asset (ROA), earning pershare (EPS) dan price earning ratio (PER) berpengaruh signifikan terhadap harga saham perusahaan rokok diBursa Efek Indonesia.

Perkembangan investasi di Indonesia semenjak krisis moneter di tahun 1998 belum benar-benar pulih seiring dengan belum stabilnya perekonomian Indonesia. Para investor selama ini cenderung hanya memilih berinvestasi pada industri-industri yang menjadi primadona pasar saja, hal ini wajar sebab para investor tersebut menginginkan pengembalian yang tinggi dari investasinya. Tetapi industri-industri yang jarang dilirik oleh investor tersebut terkadang mempunyai prospek yang bagus di masa depan. PT. Bisi Internasional tbk (BISI) didirikan pada tahun 1983 yang merupakan produsen benih hibrida untuk jagung, padi dan holtikultura dan produsen utama pestisida serta distributor pupuk terbesar di Indonesia. BISI dalam operasi kegiatan usahanya yaitu menyediakan produksi tanaman pangan benih hibrida primer yang meliputi jagung hibrida dan benih padi dan hasil yang jauh lebih tinggi. PT. Bisi Internasional tbk (BISI) telah tercatat di bursa efek Indonesia sejak 28 Mei 2007.

\section{B. Rumusan Masalah}

Berdasarkan uraian yang dipaparkan pada latar belakang tersebut di atas, maka yang menjadi rumusan masalah dalam penelitian ini yaitu:

1. Apakah Return On Assets (ROA) secara parsial berpengaruh signifikan terhadap harga saham pada PT. Bisi Internasional Tbk dari tahun 2011 hingga 2015?

2. Apakah Earning Per Share (EPS) secara parsial berpengaruh signifikan terhadap harga saham pada PT. Bisi Internasional Tbk dari tahun 2011 hingga 2015?

3. Apakah Price Earning Ratio (PER) secara parsial berpengaruh signifikan terhadap harga saham pada PT. Bisi Internasional Tbk dari tahun 2011 hingga 2015 ?

4. Apakah Return On Assets, Earning Per Share, dan Price Earnng Ratio secara simultan berpengaruh signifikan terhadap harga saham pada PT. Bisi Internasional Tbk dari tahun 2011 hingga 2015?

\section{Tujuan Penelitian}

1. Mengetahui apakah Return On Assets (ROA) secara parsial berpengaruh signifikan terhadap harga saham pada PT. Bisi Internasional Tbk dari tahun 2011 hingga 2015.

2. Mengetahui apakah Earning Per Share (EPS) secara parsial berpengaruh signifikan terhadap harga saham pada PT. Bisi Internasional Tbk dari tahun 2011 hingga 2015.

3. Mengetahui apakah Price Earning Ratio (PER) secara parsial berpengaruh signifikan terhadap harga saham pada PT. Bisi Internasional Tbk dari tahun 2011 hingga 2015.

4. Mengetahui apakah Return On Assets, Earning Per Share, dan Price Earning Ratio secara simultan berpengaruh signifikan terhadap harga saham pada PT. Bisi Internasional Tbk dari tahun 2011 hingga 2015. 


\section{Manfaat Penelitian}

Menambah pengetahuan dan keilmuan di bidang manajemen dalam menilai kinerja keuangan dan harga saham suatu perusahaan. Hasil penelitian ini dapat memberikan masukan bagi para investor dalam melakukan penanaman modal (investasi).

\section{METODE PENELITIAN}

Penelitian ini ditinjau dari analisisnya, diklasifikasikan ke dalam jenis penelitian yang mengunakan pendekatan kuantitatif. Penelitian yang menggunakan pendekatan kuantitatif menekankan analisisnya pada data-data yang berupa angka dan diolah dengan metode statistika. Metode statistika adalah bagaimana cara mengumpulkan data atau fakta, mengolah, menyajikan, menganalisa, penarikan kesimpulan serta pembuatan keputusan yang cukup beralasan berdasarkan fakta dan penganalisaan yang dilakukan. Metode statistik dalam penelitian ini yaitu dengan mencari pengaruh variabel bebas yang diberi notasi huruf $\mathrm{X}(\mathrm{X} 1=\mathrm{ROA}, \mathrm{X} 2=\mathrm{EPS}$, dan $\mathrm{X} 3=\mathrm{PER})$ terhadap variabel terikat yang diberi huruf notasi $\mathrm{Y}$ (harga saham) dengan menggunakan laporan keuangan triwulan dan daftar harga saham per tanggal laporan keuangan triwulan.

Penelitian ini dilakukan di bursa efek cabang Makassar.Populasi dalam penelitian ini yaitu menetapkan pada data keuangan berupa laporan keuangan triwulan dan harga saham per tanggal laporan keuangan triwulan. PT. Bisi Internasional Tbk yang berdiri di era 1983 dan kemudian mencatatkan sahamnya di bursa efek pada 28 Mei 2007. Jadi sampel dalam penelitian ini adalah:

1. Laporan keuangan triwulan sejak tahun 2011 hingga 2015.

2. Data harga saham penutupan per tanggal laporan keuangan triwulan.

Data penelitian merupakan laporan keuangan PT. Bisi Internasional Tbk yang memang sudah tersedia di Bursa Efek Indonesia (BEI). Sehingga laporan keuangan dan harga saham perusahaan tersebut dapat diakses dengan mudah. Data sekunder ini, penulis peroleh dari kantor cabang Bursa Efek Indonesia di Makassar yang didukung data dari situs www.idx.co.id. Teknik analisis data yang digunakan yaitu Analisis Regresi Linier Berganda. Model ini digunakan karena penelitian ini mengemukakan variabel bebas lebih dari satu, maka analisis ini digunakan untuk mengetahui pengaruh antara variabel bebas terhadap variabel terikat.

Persamaan Regresi Linier Berganda adalah sebagai berikut :

$$
\mathrm{Y}=\mathrm{a}+\mathrm{b} 1 \mathrm{ROA}+\mathrm{b} 2 \mathrm{EPS}+\mathrm{b} 3 \mathrm{PER}+\mathrm{ei}
$$

Keterangan:

$$
\begin{array}{ll}
\mathrm{Y} & =\text { Harga Saham } \\
\mathrm{a} & =\text { Konstanta } \\
\mathrm{b} 1-\mathrm{b} 3 & =\text { Koefisien regresi masing-masing variabel bebas } \\
\mathrm{ROA} & =\text { Return On Asset } \\
\mathrm{EPS} & =\text { Earning Per Share } \\
\mathrm{PER} & =\text { Price Earning Ratio } \\
\mathrm{ei} & =\text { Standar Error }
\end{array}
$$




\section{HASIL PENELITIAN DAN PEMBAHASAN}

\section{A. Hasil dan Analisis Data}

\section{Deskripsi Objek Penelitian}

PT. Bisi Internasional Tbk (sebelumnya bernama PT. Benihinti Suburintani) didirikan 22 Juni 1983 dengan nama PT. Birght Indinesia Seed Industry dan beroperasi secara komersial mulai tahun 1983. Kantor pusat BISI berdomisili di Jl. Surabaya Mojokerto km 19, Sidoarjo, dengan lokasi pabrik di Pare, Kediri. Berdasarkan anggaran dasar perusahaan, ruang lingkup kegiatan usaha BISI meliputi pembibitan dan perdagangan benih jagung, sayuran, dan buah-buahan, dan padi. Produk utama yang dihasilkan BISI dan anak usahanya adalah benih jagung (varietas unggul BISI-2, BISI12, BISI-16, BISI-18, BISI-816), benih holtikultura (sayuran dan buah-buahan Timun Hercules), benih padi (varietas unggul padi intani-2 dan Ciherang dan pestisida.

Pada tanggal 11 Mei 2007, BISI memperoleh pernyataan efektif dari BAPEPAMLK (Badan Pengawas Pasar Modal dan Lembaga Keuangan) untuk melakukan Penawaran Umum Perdana Saham BISI initial public offering (IPO) kepada masyarakat sebanyak 900.000.000 dengan nilai nominal Rp. 100,- per saham dengan harga penawaran Rp. 200,- per saham. Saham-saham tersebut kemudian dicatatkan pada Bursa Efek Indonesia (BEI) pada tanggal 28 Mei 2007. Adapun closing price harga saham PT. Bisi Internasional Tbk yaitu sebagai berikut.

Tabel 1. Closing Price Harga Saham PT. Bisi Internasional Tbk Periode 2011-2015

\begin{tabular}{|c|c|c|c|c|c|c|c|}
\hline \multirow{2}{*}{ Tahun } & \multirow{2}{*}{ Quartel } & \multicolumn{2}{|c|}{ Price (Rp) } & \multicolumn{3}{|c|}{ Trading } & \multirow{2}{*}{ Days } \\
\hline & & Close & Date & Volume & Value & Freq. & \\
\hline \multirow{3}{*}{2011} & Q1 & 1.730 & $03 / 31$ & 199.313 .500 & 285.445 .900 .000 & 27.786 & 62 \\
\hline & Q3 & 1.000 & $09 / 30$ & 780.936 .500 & 1.102 .141 .600 .000 & 92.953 & 183 \\
\hline & Q4 & 910 & $12 / 30$ & 969.749 .000 & 1.283 .020 .825 .000 & 112.956 & 247 \\
\hline \multirow{4}{*}{2012} & Q1 & 860 & $03 / 30$ & 117.553 .500 & 109.479 .355 .000 & 14.079 & 63 \\
\hline & Q2 & 790 & $06 / 29$ & 321.159 .500 & 277.452 .020 .000 & 31.044 & 125 \\
\hline & Q3 & 1.090 & $09 / 28$ & 869.371 .000 & 908.915 .230 .000 & 76.748 & 186 \\
\hline & Q4 & 790 & $12 / 28$ & 1.020 .956 .500 & 1.061 .888 .240 .000 & 94.130 & 246 \\
\hline \multirow{4}{*}{2013} & Q1 & 860 & $03 / 28$ & 466.507 .500 & 420.568 .455 .000 & 30.663 & 60 \\
\hline & Q2 & 680 & $06 / 28$ & 784.296 .000 & 673.706 .570 .000 & 55.570 & 123 \\
\hline & Q3 & 610 & $09 / 30$ & 949.387 .500 & 779.963 .050 .000 & 78.318 & 184 \\
\hline & Q4 & 560 & $12 / 30$ & 998.140 .000 & 809.299 .150 .000 & 86.951 & 244 \\
\hline \multirow{4}{*}{2014} & Q1 & 660 & $03 / 28$ & 144.695 .000 & 91.349 .128 .000 & 23.134 & 60 \\
\hline & Q2 & 520 & $06 / 30$ & 252.608 .300 & 154.530 .577 .500 & 42.278 & 119 \\
\hline & Q3 & 494 & $09 / 30$ & 349.559 .900 & 205.889 .611 .200 & 59.982 & 179 \\
\hline & Q4 & 790 & $12 / 30$ & 572.243 .900 & 359.020 .045 .700 & 81.034 & 242 \\
\hline \multirow{4}{*}{2015} & Q1 & 1.310 & $03 / 31$ & 436.774 .100 & 486.941 .237 .000 & 48.814 & 62 \\
\hline & Q2 & 1.600 & $06 / 30$ & 629.360 .600 & 72.339 .161 .500 & 83.078 & 123 \\
\hline & Q3 & 1.100 & $09 / 30$ & 698.717 .400 & 856.242 .472 .500 & 112.149 & 183 \\
\hline & Q4 & 1.350 & $12 / 30$ & 791.320 .800 & 977.614 .459 .000 & 144.815 & 244 \\
\hline
\end{tabular}

Sumber : IDX Statistic, Indonesia Stock Exchange, data yang diolah 


\section{Return On Assets (ROA)}

Return On Asset (ROA) yaitu rasio yang digunakan untuk mengukur kemampuan manajemen keuangan perusahaan dalam memperoleh keuntungan (laba) secara keseluruhan.

Tabel 2. Hasil Perhitungan Return On Asset (ROA)

\begin{tabular}{|c|c|c|c|c|}
\hline Tahun & Quartel & $\begin{array}{c}\text { Laba Bersih Sebelum } \\
\text { Pajak } \\
\text { (dalam jutaan rupiah) }\end{array}$ & $\begin{array}{c}\text { Total Aktiva/ Aset } \\
\text { (dalam Jutaan } \\
\text { Rupiah) }\end{array}$ & $\begin{array}{c}\text { Hasil } \\
\text { Perhitungan } \\
(\%)\end{array}$ \\
\hline \multirow{3}{*}{2011} & I & 54.845 & 1.407 .843 & 3,8 \\
\hline & III & 131.092 & 1.372 .094 & 9,5 \\
\hline & IV & 191.149 & 1.518 .534 & 12,5 \\
\hline \multirow{4}{*}{2012} & I & 87.416 & 1.524 .245 & 5,7 \\
\hline & II & 105.224 & 1.516 .894 & 6,9 \\
\hline & III & 130.222 & 1.477 .610 & 8,8 \\
\hline & IV & 169.396 & 1.578 .603 & 10,7 \\
\hline \multirow{4}{*}{2013} & I & 73.077 & 1.582 .605 & 4,6 \\
\hline & II & 116.960 & 1.646 .941 & 7,1 \\
\hline & III & 144.039 & 1.620 .949 & 8,8 \\
\hline & IV & 156.235 & 1.712 .683 & 9,1 \\
\hline \multirow{4}{*}{2014} & I & 35.891 & 1.714 .773 & 2 \\
\hline & II & 32.315 & 1.726 .578 & 1,8 \\
\hline & III & 112.885 & 1.786 .760 & 6,3 \\
\hline & IV & 209.152 & 1.871 .043 & 11,1 \\
\hline \multirow{4}{*}{2015} & I & 59.678 & 1.884 .249 & 3,1 \\
\hline & II & 124.653 & 1.866 .361 & 6,6 \\
\hline & III & 236.064 & 2.008 .436 & 11,7 \\
\hline & IV & 331.593 & 2.141 .600 & 15,4 \\
\hline
\end{tabular}

Sumber : Laporan Keuagan PT. Bisi Internasional Tbk, data diolah.

Dari tabel 2 di atas, dapat dijelaskan bahwa perkembangan hasil perhitungan ROA (Return On Asset) PT. Bisi Internasional tbk terendah adalah pada tahun 2014 triwulan kedua dengan nilai ROA sebesar $1,8 \%$. Menurut laporan direksi dan laporan keuangan perusahaan tahun 2014, adanya penurunan nilai ROA disebabkan karena laba bersih sebelum pajak dan total penjualan produk seperti benih jagung, benih, padi, holtikultura dan pestisida menurun. Sedangkan yang tertinggi yaitu pada tahun 2015 triwulan ke empat dengan nilai ROA sebesar 15,4 \%. Menurut laporan direksi dan laporan keuangan perusahaan tahun 2015, adanya kenaikan nilai ROA disebabkan karena laba bersih dan total penjualan produk seperti benih jagung, benih, padi, holtikultura dan pestisida meningkat.

\section{Earning Per Share (EPS)}

Earning Per Share (EPS) yaitu Rasio yang digunakan untuk menunjukkan tingkat keuntungan yang diperoleh dari setiap lembar saham dengan membandingkan antara laba bersih setelah pajak dengan saham yang diterbitkan oleh perusahaan. 
Tabel 3. Hasil Perhitungan Earning Per Share (EPS)

\begin{tabular}{|c|c|c|c|c|}
\hline Tahun & Quartel & $\begin{array}{c}\text { Laba Bersih Setelah } \\
\text { Pajak } \\
\text { (dalam jutaan rupiah) }\end{array}$ & $\begin{array}{c}\text { Jumlah Saham } \\
\text { yang Diterbitkan } \\
\text { (dalam jutaan } \\
\text { rupiah) }\end{array}$ & $\begin{array}{c}\text { Hasil } \\
\text { Perhitungan }\end{array}$ \\
\hline \multirow{3}{*}{2011} & I & 41.621 & 3.000 & 13,8 \\
\hline & III & 100.904 & 3.000 & 33,6 \\
\hline & IV & 148.092 & 3.000 & 49,3 \\
\hline \multirow{4}{*}{2012} & I & 68.571 & 3.000 & 22,8 \\
\hline & II & 82.625 & 3.000 & 27,5 \\
\hline & III & 101.968 & 3.000 & 33,9 \\
\hline & IV & 129.321 & 3.000 & 43,1 \\
\hline \multirow{4}{*}{2013} & I & 54.533 & 3.000 & 18,1 \\
\hline & II & 92.380 & 3.000 & 30,7 \\
\hline & III & 113.518 & 3.000 & 37,8 \\
\hline & IV & 127.025 & 3.000 & 42,3 \\
\hline \multirow{4}{*}{2014} & I & 28.212 & 3.000 & 9,4 \\
\hline & II & 25.743 & 3.000 & 8,5 \\
\hline & III & 89.754 & 3.000 & 29,9 \\
\hline & IV & 165.263 & 3.000 & 55 \\
\hline \multirow{4}{*}{2015} & I & 48.381 & 3.000 & 16,1 \\
\hline & II & 98.700 & 3.000 & 32,9 \\
\hline & III & 187.729 & 3.000 & 62,5 \\
\hline & IV & 265.070 & 3.000 & 88,3 \\
\hline
\end{tabular}

Sumber : Laporan Keuagan PT. Bisi Internasional Tbk, data diolah.

Dari tabel 3 di atas, dapat dijelaskan bahwa perkembangan hasil perhitungan EPS (Earning Per Share) PT. Bisi Internasional tbk terendah adalah pada tahun 2014 triwulan kedua dengan nilai EPS sebesar 9,4. Adanya penurunan nilai EPS tersebut di atas seperti diperoleh dari laporan keuangan perusahaan pada tahun 2014 disebabkan karena adanya penurunan laba bersih setelah pajak perusahaan dan penurunan harga jual benih jagung, benih padi, dan holtikultura pada tahun tersebut sehingga keuntungan yang diperoleh dari setiap lembar saham perusahaan menurun.

\section{Price Earning Ratio (PER)}

Price Earning Ratio (PER) yaitu perbandingan harga saham dengan laba per lembar saham yang kemudian menjadi ukuran penting untuk landasan seorang investor membeli saham sebuah perusahaan.

Tabel 4. Hasil Perhitungan PriceEarning Ratio (PER)

\begin{tabular}{|c|c|c|c|c|}
\hline Tahun & Quartel & Harga Pasar Saham & $\begin{array}{c}\text { Laba Per Lembar } \\
\text { Saham }\end{array}$ & $\begin{array}{c}\text { Hasil } \\
\text { Perhitungan }\end{array}$ \\
\hline \multirow{3}{*}{2011} & I & 1.730 & 14 & 123,5 \\
\cline { 2 - 5 } & III & 1.000 & 34 & 29,4 \\
\cline { 2 - 5 } & IV & 910 & 49 & 18,5 \\
\hline \multirow{2}{*}{2012} & I & 860 & 23 & 37,3 \\
\cline { 2 - 5 } & II & 790 & 28 & 28,2 \\
\hline
\end{tabular}




\begin{tabular}{|c|c|c|c|c|}
\hline & III & 1.090 & 34 & 32 \\
\hline & IV & 790 & 43 & 18,3 \\
\hline \multirow{4}{*}{2013} & I & 860 & 18 & 47,7 \\
\hline & II & 680 & 31 & 21,9 \\
\hline & III & 610 & 38 & 16 \\
\hline & IV & 560 & 42 & 13,3 \\
\hline \multirow{4}{*}{2014} & I & 660 & 9 & 73,3 \\
\hline & II & 520 & 9 & 57,7 \\
\hline & III & 494 & 30 & 16,4 \\
\hline & IV & 790 & 55 & 14,3 \\
\hline \multirow{4}{*}{2015} & I & 1.310 & 16 & 81,8 \\
\hline & II & 1.600 & 33 & 48,4 \\
\hline & III & 1.100 & 63 & 17,4 \\
\hline & IV & 1.350 & 88 & 15,3 \\
\hline
\end{tabular}

Sumber : Laporan Keuagan PT. Bisi Internasional Tbk, data diolah.

Dari gambar 4.4 di atas, dapat dijelaskan bahwa perkembangan hasil perhitungan PER (Price Earning Ratio) PT. Bisi Internasional tbk terendah adalah pada tahun 2013 triwulan ke empat dengan nilai PER sebesar 13,3. Penurunan ini diakibatkan oleh turunnya harga penutupan saham dan naiknya laba per lembar saham perusahaan yang diperoleh dari IDX statistic.

\section{Pengujian Hipotesis}

Pengujian atas hipotesis dalam penelitian ini dilakukan dengan menggunakan alat analisis statistik, yaitu SPSS for Windows Release 23,00.

\section{a. Analisis Regresi Linier Berganda}

Berdasarkan perhitungan dengan menggunakan program SPSS for Windows Release 23,00 diperoleh hasil regresi sebagai berikut:

Tabel 5. Hasil Analisis Regresi Berganda

\begin{tabular}{|c|c|c|c|c|c|c|}
\hline \multirow{2}{*}{ Model } & \multicolumn{2}{|c|}{$\begin{array}{c}\text { Unstandardized } \\
\text { Coefficients }\end{array}$} & $\begin{array}{c}\text { Standardized } \\
\text { Coefficients }\end{array}$ & \multirow{2}{*}{ T } & Sig. & $\begin{array}{c}\text { Correlations } \\
\text { Partial }\end{array}$ \\
\cline { 2 - 6 } & B & Std. Error & Beta & & & \\
\hline (Constant) & -130.837 & 227.598 & & -.575 & .574 & \\
ROA & 6.757 & 2.882 & .739 & 2.395 & .030 & .526 \\
EPS & .325 & .450 & .184 & .722 & .482 & .183 \\
PER & 1.275 & .250 & 1.110 & 5.100 & .000 & .778 \\
\hline
\end{tabular}

a. Dependent Variable: Harga Saham

Sumber: Data sekunder yang diolah.

\section{b. Pengujian Secara Parsial (Uji t)}

Pengujian secara parsial untuk mengetahui apakah ada pengaruh antara ROA, EPS dan PERterhadap harga saham PT. Bisi Internasional Tbk. Berdasarkan hasil perhitungan SPSS for Windows Release 23,00 dapat di lihat pada Tabel 5, yaitu: 


\section{1) Return On Asset (ROA)}

Berdasarkan hasil perhitungan dengan menggunakan program SPSS for Windows Release 23,00 diperoleh nilai signifikansi untuk variabel ROA sebesar 0,03. Ketentuan pengambilan keputusan hipotesis diterima atau ditolak didasarkan pada besarnya nilai signifikansi. Jika signifikansi lebih kecil atau sama dengan $0.05(<0.05)$, maka hipotesis kerja diterima dan sebaliknya. Hasil penelitian diperoleh nilai signifikansi sebesar 0,03 yang lebih besar dari $0,05(0,03<0.05)$, maka disimpulkan bahwa hipotesis kerja $(\mathrm{H} 1)$ yang berbunyi "ada pengaruh antara ROA terhadap Harga Saham pada PT. Bisi Internasional Tbk", diterima. Pada perbandingan nilai t hitung dengan $\mathrm{t}$ tabel, dimana $\mathrm{t}$ hitung $=2,395$ sedangkan nilai $\mathrm{t}$ tabel pada $\mathrm{df}=\mathrm{n}-\mathrm{k}-1=19-3-1=15$ adalah 2,131 . Sehinggat hitung lebih besar dari nilai tabel $(2,395>2,131)$, maka $(\mathrm{H} 1)$ diterima yaitu ROA berpengaruh terhadap harga saham PT. Bisi Internasional Tbk.

\section{2) Earning Per Share (EPS)}

Berdasarkan hasil perhitungan dengan menggunakan program SPSS for Windows Release 23,00 diperoleh nilai signifikansi untuk variabel EPS sebesar 0,482. Ketentuan pengambilan keputusan hipotesis diterima atau ditolak didasarkan pada besarnya nilai signifikansi. Jika signifikansi lebih kecil atau sama dengan 0.05 , maka hipotesis kerja diterima dan sebaliknya. Hasil penelitian diperoleh nilai signifikansi sebesar 0,482 yang lebih besar dari 0,05(0,482>0.05), maka hipotesis kerja (H2) yang berbunyi "ada pengaruh antara EPS terhadap Harga Saham pada PT. Bisi Internasional Tbk", ditolak. Pada perbandingan nilai t hitung dengan $t$ tabel, dimana $t$ hitung $=0,772$ sedangkan nilai $t$ tabel padadf $=\mathrm{n}-\mathrm{k}-1=19-3-1=15$ adalah 2,131. Sehinggat hitung lebih kecil dari nilai tabel $(0,772<2,131)$, maka $(\mathrm{H} 2)$ ditolak yaitu EPS tidak berpengaruh terhadap harga saham PT. Bisi Internasional Tbk.

\section{3) Price Earning Ratio (PER)}

Berdasarkan hasil perhitungan dengan menggunakan program SPSS for Windows Release 23,00 diperoleh nilai signifikansi untuk variabel PER sebesar 0,000. Ketentuan pengambilan keputusan hipotesis diterima atau ditolak didasarkan pada besarnya nilai signifikansi. Jika signifikansi lebih kecil atau sama dengan $0.05(<0.05)$, maka hipotesis kerja diterima dan sebaliknya. Hasil penelitian diperoleh nilai signifikansi sebesar 0,000 $(<0.05)$, maka hipotesis kerja (H3) yang berbunyi "ada pengaruh antara PER terhadap Harga Saham pada PT. Bisi Internasional Tbk", diterima. Pada perbandingan nilai $t$ hitung dengan $\mathrm{t}$ tabel, nilai $\mathrm{t}$ dengan nilai $\mathrm{df}=\mathrm{n}-\mathrm{k}-1=19-3-1=15$, maka nilai $\mathrm{t}$ tabel diperoleh yaitu 2,131. Pada tabel 4.6 nilai EPS 5,100 > 2,131, maka (H3) diterima yaitu PER berpengaruh terhadap harga saham PT. Bisi Internasional Tbk.

\section{c. Pengujian Secara Simultan (Uji F)}

Pengujian secara simultan untuk mengetahui apakah ada pengaruh antara variabel X1 (Return On Asset), variabel X2 (Earning Per Share), dan variabel X3 (Price Earning Ratio) (H4) secara bersama-sama terhadap variabel Y (Harga Saham) pada PT. Bisi Internasional Tbk. Berdasarkan hasil perhitungan program SPSS for Windows Release 23,00 dapat dilihat pada tabel diberikut ini: 
Tabel 6. Uji Secara Simultan

ANOVA $^{\mathrm{a}}$

\begin{tabular}{|l|r|r|r|r|r|}
\hline \multicolumn{1}{|c|}{ Model } & \multicolumn{1}{c|}{$\begin{array}{c}\text { Sum of } \\
\text { Squares }\end{array}$} & Df & Mean Square & F & Sig. \\
\hline 1 Regression & 1477525.305 & 3 & 492508.435 & 9.311 & $.001^{\text {b }}$ \\
Residual & 793409.853 & 15 & 52893.990 & & \\
Total & 2270935.158 & 18 & & & \\
\hline
\end{tabular}

Sumber : Data sekunder yang diolah.

Berdasarkan hasil uji ANOVA atau $\mathrm{F}$ test diperoleh $\mathrm{F}$ hitung sebesar 9,311 dengan probabilitas 0,001 , karena probabilitas jauh lebih kecil dari 0,05 . Hal ini berarti hipotesis kerja (H4) yang berbunyi "ada pengaruh antara X1 (Return On Assets), variabel X2 (Earning Per Share), dan variabel X3 (Price Earning Ratio) secara bersama-sama terhadap variabel Y (Harga Saham) pada PT. Bisi Internasional Tbk", diterima.

\section{B. Pembahasan Hasil Penelitian}

Berdasarkan hasil pengujian secara statistik dapat terlihat dengan jelas bahwa secara parsial (individu) variabel bebas (ROA dan PER) dapat mempengaruhi variabel terikat (harga saham), sedangkan variabel bebas (EPS) tidak dapat mempengaruhi variabel terikat (harga saham). Berdasarkan hasil perhitungan didapat tingkat signifikansi untuk variabel Return On Asset (ROA) sebesar 0,03, untuk variabel Earning Per Share (EPS) sebesar 0,482 dan untuk Price Earning Ratio (PER) sebesar 0,000.

Berdasarkan hasil uji hipotesis, bahwa variabel Return On Asset (ROA) berpengaruh signifikan terhadap harga saham PT. Bisi Internasional tbk. Apabila suatu perusahaan mempunyai ROA yang tinggi maka perusahaan tersebut akan menghasilkan laba yang tinggi pula, dengan laba yang tinggi maka semakin tinggi pula besarnya deviden yang akan dibagikan kepada investor. Kondisi seperti inilah yang akan membuat daya tarik investor untuk memiliki saham perusahaan tersebut meningkat. Selain itu, dapat diketahui juga bahwa disamping memperoleh keuntungan dari capital gain investor juga memperhatikan tingkat pencapaian profitabilitas perusahaan dengan melihat dari besarnya rasio return on assets (ROA) untuk memutuskan investasi dalam bentuk saham, sehingga rasio ini dapat dijadikan sebagai salah satu perhatian atau faktor oleh investor didalam memprediksi mengenai harga saham perusahaan. Nilai signifikansi dari ROA yaitu $0,03<$ standar signifikan yaitu $\alpha 0,05$ maka ROA dapat dikatakan berpengaruh signifikan terhadap harga saham.

Berdasarkan uji hipotesis, bahwa variabel Earning Per Share (EPS) tidak berpengaruh signifikan terhadap harga saham. EPS adalah rasio yang digunakan untuk menunjukan tingkat keuntungan yang diperoleh setiap lembar saham dengan membandingkan antara laba bersih setelah pajak dengan saham yang diterbitkan oleh perusahaan. EPS tidak berpengaruh signifikan terhadap harga saham PT. Bisi Internasional tbk karena menurunnya perolehan sebagian besar tingkat keuntungan dari setiap lembar saham perusahaan dan harga saham yang cenderung fluktuatif dari tahun 
2011 hingga 2015 yang berpengaruh pada kepercayaan para investor. Nilai signifikansi dari EPS yaitu 0,482 > standar signifikan yaitu $\alpha 0,05$ maka EPS tidak dapat dikatakan berpengaruh signifikan terhadap harga saham.

Berdasarkan hasil uji hipotesis, bahwa variabel Price Earning Ratio (PER) berpengaruh signifikan terhadap harga saham PT. Bisi Internasional tbk. Dimana investor memperhatikan rasio ini dalam mengambil keputusan untuk menanamkan dananya pada perusahaan. Sehingga para investor mampu memprediksi perubahan harga saham pada PT. Bisi Internasional Tbk dilihat dari nilai PER, karena rasio ini merupakan perbandingan antara harga saham dengan laba per saham yang kemudian menjadi ukuran penting untuk landasan pertimbangan seorang investor membeli saham sebuah perusahaan. Hal inilah yang mengakibatkan daya tarik investor dalam menanamkan dananya pada perusahaan PT. Bisi Internasional Tbk meningkat, karena dengan PER juga dapat menggambarkan apresiasi pasar terhadap kemampuan perusahaan dalam menghasilkan laba. Nilai signifikansi dari PER yaitu $0,000<$ standar signifikan yaitu $\alpha$ 0,05 maka PER dapat dikatakan berpengaruh signifikan terhadap harga saham.

Secara simultan, hasil penelitian ini menunjukkan bahwa variabel bebas yaitu rasio keuangan yaitu (ROA, EPS dan PER) mempunyai pengaruh yang signifikan terhadap harga saham pada PT. Bisi Internasional Tbk. Hasil penelitian tersebut menyatakan bahwa rasio keuangan ROA, EPS, dan PER secara simultan berpengaruh terhadap harga saham. Nilai signifikansi dari ROA, EPS dan PER yaitu 0,001 < standar signifikan yaitu $\alpha$ 0,05 maka secara simultan variabel ROA, EPS dan PER dapat dikatakan berpengaruh signifikan terhadap harga saham. Hasil ini menunjukkan bahwa investor dalam pengambilan putusan investasi dengan mempertimbangkan tingkat harga saham, tingkat pengembalian yang akan diperoleh dan mempertimbangkan kemampuan alat-alat likuid terhadap kewajiban perusahaan. Hal ini dapat menarik para investor untuk bergabung dan membeli saham perusahaan karena prospek pertumbuhan perusahaan juga dinyatakan dalam harga-harga saham, dan perusahaan-perusahaan tumbuh dan akan memiliki nilai pasar yang lebih tinggi secara relatif untuk setiap aktiva yang dimiliki.

\section{PENUTUP}

Berdasarkan dari hasil penelitian dan pembahasan pada penelitian ini, maka dapat disimpulkan sebagai berikut:

1. Secara parsial (H1) variabel Return On Asset (ROA) berpengaruh signifikan terhadap harga saham pada PT. Bisi Internasional Tbk dengan tingkat signifikansi $0,03<\alpha 0,05$ dan pada perbandingan nilai t hitung ROA yaitu 2,395> t tabel yaitu 2,131, maka H1 diterima. Artinya kemampuan manajemen perusahaan dalam menghasilkan laba dari total aktiva yang digunakan sudah sesuai dengan tujuan perusahaan atau berjalan baik.

2. Secara parsial (H2) variabel Earning Per Share (EPS) tidak berpengaruh terhadap harga saham pada PT. Bisi Internasional Tbk dengan tingkat signifikansi 0,482> $\alpha 0,05$ dan pada perbandingan nilai t hitung EPS yaitu $0,722<\mathrm{t}$ tabel yaitu 2,131, maka H2 ditolak. Artinya menurunnya perolehan sebagian besar tingkat keuntungan dari setiap lembar saham perusahaan dan harga saham yang 
cenderung fluktuatif dari tahun 2011 hingga 2015 yang berpengaruh pada kepercayaan para investor.

3. Secara parsial (H3) variabel Price Earning Ratio (PER) berpengaruh terhadap harga saham pada PT. Bisi Internasional Tbk dengan tingkat signifikansi 0,000 < $\alpha 0,05$ dan pada perbandingan nilai $t$ hitung PER yaitu 5,100 $>\mathrm{t}$ tabel yaitu 2,131, maka H3 diterima. Artinya perbandingan harga saham dengan laba per saham perusahaan ini sangat baik dan penting untuk landasan pertimbangan seorang investor dalam membeli saham perusahaan ini. Selain itu, perusahan ini juga telah menggambarkan apresiasi pasar terhadap kemampuan perusahaan dalam menghasilkan laba.

4. Secara simultan (H4) yang terdiri dari rasio Return On Asset (ROA), Earning Per Share (EPS), dan Price Earning Ratio (PER)berpengaruh signifikan terhadap harga saham PT. Bisi Internasional Tbk dengan tingkat signifikansi $0,001<\alpha$ 0,05, maka $\mathrm{H} 4$ diterima. Atinya kemampuan manajemen perusahaan dalam menghasilkan laba dari total aktiva yang digunakan dan keuntungan yang diperoleh dari setiap lembar saham serta perbandingan harga saham dengan laba per saham perusahaan ini sangat baik dalam dalam kinerjanya di masa mendatang.

\section{DAFTAR PUSTAKA}

Al-Maqassary, Ardi. 2013.Pengertian Kinerja.http://www.e-jurnal.com.

Anoraga, Pandji. 2001.Pengantar Pasar Modal.Edisi revisi. Jakarta: Rineka Cipta.

Artatik, S. 2007.Pengaruh Earning Per Share (EPS) dan Price Earning Ratio (PER) terhadap Return Saham pada Perusahaan Manufaktur di Bursa Efek Jakarta. Skripsi.Semarang: Universitas Diponegoro.

Brigham, Eugene F. dan J. F. Houston. 2001.Manajemen Keuangan. Edisi Kedelapan, Jakarta: Erlangga.

Jogiyanto, H. M. 2003.Teori Portofolio dan Analisis Investasi.Edisi kedua.

Martono dan Harjito, Agus. 2005.Manajemen Keuangan.Yogyakarta:Ekonisia.

Otoritas Jasa Keuangan. 2015.Buku Saku Pasar Modal.Edisi 2015. Jakarta: Direktorat Pengaturan Pasar Modal Otoritas Jasa Keuangan, 10710.

Sartono, A. 2005.Manajemen Keuangan. Edisi Ketiga.Yogyakarta: BPFE.

Sugiyono. 2011.Metode Peelitian Bisnis.Bandung: Alfabet.

www.idx.co.id 